Walton, B. J. 1976: Mapping of Archaean rocks in the inner Godthåbsfjord region, southern West Greenland. Rapp. Grønlands geol. Unders. 80, 72-77.

V.R.M., Atangmik, 3912 Sukkertoppen, Greenland.
B.J.W., Department of Chemistry and Geology, Portsmouth Polytechnic, Burnaby Road, Portsmouth P01 $3 Q L$, U.K.

\title{
Field work in the Ivisârtoq area, inner Godthåbsfjord, southern West Greenland
}

\author{
C. R. L. Friend and R. P. Hall
}

The field work reported on here is part of the 1:500000 scale mapping programme of the Godthåbsfjord region (Allaart et al., this report). Ivisârtoq lies some $110 \mathrm{~km}$ north-east of Godthåb $\left(50^{\circ} 00^{\prime} \mathrm{W}, 64^{\circ} 45^{\prime} \mathrm{N}\right.$, map $64 \mathrm{~V} 2$ Kapisigdlit), (fig. 15). The area belongs to the central Archaean block of West Greenland (Pulvertaft, 1968) which in the Godthabsfjord region has been shown to contain gneisses and associated amphibolites which may be broadly divided into two complexes (McGregor, 1973). The Amîtsoq gneisses and included amphibolites have ages of $c .3700 \mathrm{~m} . y$. (Black et al., 1971; Moorbath et al., 1972), and the Nûk gneisses and associated amphibolites and anorthosites of c. 3000 m.y. (Pankhurst et al., 1973; Moorbath \& Pankhurst, 1976).

There is little previously published information on the Ivisârtoq area. Bridgwater $e t$ al. (1976) grouped the main belt of supracrustals in the area together with the Malene supracrustal rocks and their equivalents both on petrological grounds and because earlier reconnaissance work did not reveal the presence of demonstrable Ameralik dykes cutting either the supracrustals or the granitic gneisses intrusive into their margins. A single sample of metasediment collected for age determinations during the earlier reconnaissance yielded zircons giving a ${ }^{207} \mathrm{~Pb} /{ }^{206} \mathrm{~Pb}$ age of $2580 \mathrm{~m}$.y. and ${ }^{204} \mathrm{~Pb} /{ }^{238} \mathrm{U}$ versus ${ }^{207} \mathrm{~Pb} /{ }^{235} \mathrm{U}$ values very close to a concordia intercept at approximately $2550 \mathrm{~m}$.y. (Baadsgaard, 1976) interpreted as the probable result of metamorphic effects from the Qôrqut granite.

This report describes the field relationships of the rock types and contains the first report of ultramafic pillow lavas from the Godthåbsfjord region.

\section{Rock units of the Ivisârtoq area}

The area consists of three main rock types of various generations: quartzo-feldspathic gneisses, amphibolites (with associated ultramafic and meta-sedimentary material) and anorthosites. The gneisses can be divided into two categories, an older complex which 


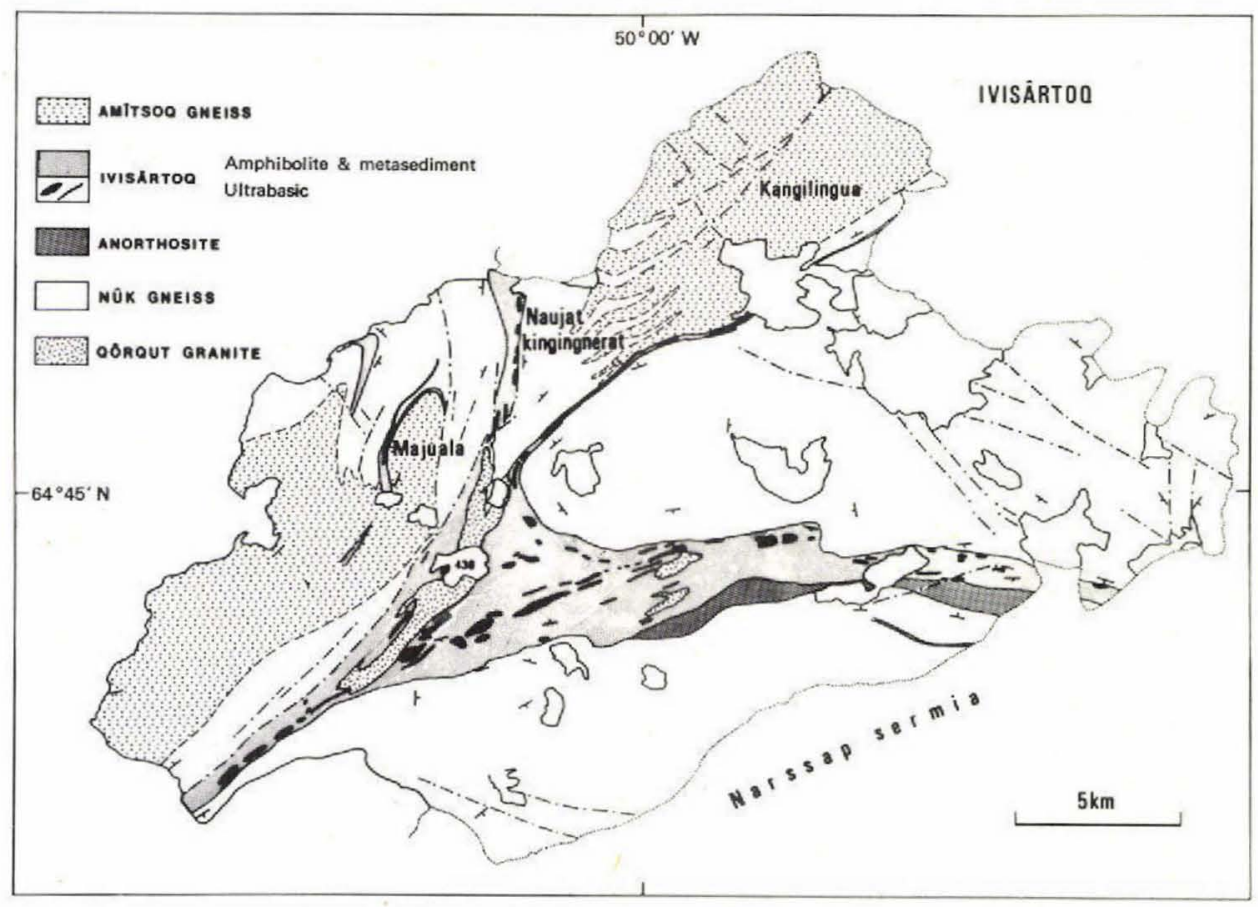

Fig. 15. Geological map of the Ivisârtoq area, Godthåbsfjord, southern West Greenland.

contains numerous amphibolitised dykes, and a younger complex which is usually without dykes. Applying the field criteria of McGregor (1973), the older gneisses are equivalent to the Amitsoq gneisses and the dykes equivalent to the Ameralik dykes. The younger phases correspond to the Nûk-generation gneisses, with a proportion belonging to the even younger 'Qôrqut' phase of granitic gneisses.

\section{Amîtsoq gneiss complex}

The best preserved remnants of the Amitsoq gneiss complex are found in the north of the area to the west of Majuala and on Kangilingua (fig. 15). They consist of a series of heterogeneous, finely banded, medium-grained biotite gneisses possessing a well-developed stromatic structure. Generally the gneisses between the pegmatite are mesocratic, imparting a distinctive 'zebra-striped' appearance to the outcrops. Isoclinal fold hinges and parasitic S and $\mathrm{Z}$ folds commonly deform the metamorphic fabric.

Abundant Ameralik dykes cut a metamorphic fabric of the gneisses, but are themselves isoclinally folded. The dykes comprise two lithological types: (a) a homogeneous black amphibolite, and (b) a similar amphibolite containing plagioclase crystals that occur either randomly or as a progressive concentration on one side of a dyke. It appears that one type may grade into the other. 
The Amîtsoq gneisses contain inclusions which correspond to the lithological types of the pre-Amîtsoq supracrustal association (McGregor \& Bridgwater, 1973; Bridgwater et al., 1976) which have been termed the Akilia association (McGregor \& Mason, in press). They occur generally as discontinuous strips and boudin trains within the Amîtsoq gneiss layering. One horizon, $50 \times 1000 \mathrm{~m}$, has an association of amphibolites, ultramafics and metasedimentary rocks.

The Akilia association comprises a series which grades from magnetite quartzite to clinopyroxene quartzite, including a more mafic variety consisting of garnetclinopyroxene-magnetite-quartz assemblages. In all cases the quartz is a very distinctive grey-brown colour, with an irridescent, conchoidal fracture when fresh. The clinopyroxene occurs as large subhedral to euhedral, pale-green porphyroblasts up to $2 \mathrm{~cm}$ across, which are rimmed by secondary, dark-green amphibole.

The ultramafic inclusions may be divided into two groups: (a) those which contain abundant olivine set in varying matrices of ortho- and clino-amphibole, chlorite, talc and serpentine and (b) olivine-free types which are dominantly hornblenditic or a mixture of amphibole and clinopyroxene. The hornblenditic bodies appear totally recrystallised, probably forming from pyroxenite masses by hydration during deformation. Generally the ultramafics occur as relatively small bodies, variably scattered throughout the Amitsoq gneisses, many of the smallest bodies having reacted to talc-chlorite-serpentine balls.

Amphibolite within the Amitsoq gneisses is of problematical origin. Cross-cutting relationships of the Ameralik dykes have been modified by deformation that produced parallelism, break-up and migmatisation of the dykes (McGregor, 1973). Hence, much of the amphibolite may be of this source rather than of pre-Amitsoq age. However, recognition of amphibolites associated with characteristic Akilia meta-sedimentary rocks supports, in part, their correlation with rocks of Akilia age.

A thin, kilometre long train of leucogabbroic anorthosite fragments occurs within the Amitsoq gneisses of Kangilingua. These fragments may be up to $2 \mathrm{~m}$ in diameter and are surrounded by gneisses which are cut by many well preserved Ameralik dykes. At several localities two or three of these dykes run between the anorthosite xenoliths which are spread over $10-15 \mathrm{~m}$. This relationship precludes a post-Ameralik dyke origin for these anorthosites, although whether they are pre-or post-Amîtsoq gneiss remains uncertain.

\section{Ivisârtoq Amphibolite Complex}

The area is dominated by the Ivisârtoq amphibolite complex which consists of homogeneous, finely banded, 'striped' and pillowed amphibolites with interlayered ultramafic and meta-sedimentary rocks. Several pillowed sequences are exceptionally well preserved and way-up criteria are evident. The best of the pillowed amphibolites are found east of the $430 \mathrm{~m}$ lake (fig. 15) and continue southwards across strike. The pillows vary in shape and size as a function of their position within fold structures. Generally, the least deformed examples are $50-75 \mathrm{~cm}$ by $30 \mathrm{~cm}$ in cross-section. They are composed of fine-grained, grey-green amphibolite surrounded by a $2-3 \mathrm{~cm}$ thick marginal zone of darker, more amphibole-rich material. Separating adjacent pillows are thin layers of leucocratic material, which effectively outline each individual pillow.

Along strike the pillow sequences occur in many states of deformation. South of the $430 \mathrm{~m}$ 
lake the pillows are intensely lineated in the core of a major fold. The individual pillow shapes are still recognisable and, at suitable outcrops may be seen as very long rods (cf. Dawes, 1970; Friend, 1975). Eastwards the pillows are in the limb of the fold and occur as highly flattened elliptical bodies.

'Striped' amphibolites are produced from progressively altered pillows by intense deformation. Skarn minerals (epidote and diopside) form in the cores of pillows and progressively develop towards the margins. These yellow-green cores contrast with the unaltered grey pillow material and black margins. On deformation multi-layered, 'striped' sequences result (Friend, 1975) in which individual layers are usually not more than $5 \mathrm{~cm}$ thick, but are often at least $2 \mathrm{~m}$ long.

Associated with the major undeformed pillow horizons are layers of ultramafic pillows which are composed almost entirely of hornblende. These pillows pass laterally into layers consisting of irregular pods and lenses of hornblendite set in a matrix of amphibolite. This rock type appears to be an original depositional feature and probably represents a pillow breccia. Locally hornblendite layers form significant parts of the sequence. These have probably formed by deformation of the ultramafic pillow horizons.

The meta-sedimentary rocks are varied, discontinuous bodies and are often finely interlayered with the amphibolites. The majority vary from fine-grained, semi-pelitic gneisses to less common quartzites. They frequently stand out because of their striking red, orange and yellow weathering colours due to the weathering of pyrite and chalcopyrite. One exceptional meta-sediment was found in which there occurs euhedral to subhedral garnets measuring up to $15 \mathrm{~cm}$ in diameter. These garnets contain $1 \mathrm{~cm}$ long, euhedral staurolite crystals, one example enclosing nine staurolite crystals.

Occasional layers of anthophyllite-biotite schists were found within the amphibolites. Some of these grade into a very leucocratic, garnetiferous amphibolite, locally interlayered with brownish weathering amphibolite. These rocks may represent intermediate volcanics, although no field evidence was found to substantiate this.

Throughout the Ivisârtoq amphibolite complex a series of yellowish and brownishweathering ultrabasic bodies occur, interlayered with both the amphibolites and metasedimentary rocks. They occur as boudinaged horizons about 20-100 $\mathrm{m}$ thick and up to a kilometre long. In two cases relict isoclinal fold hinges have been preserved. The rocks are generally recrystallised, consisting of metamorphic assemblages. One or two examples exist with relicts of a coarse-grained texture consisting of large, bladed olivine crystals measuring up to $40 \times 10 \mathrm{~cm}$, set in a matrix of chlorite, talc and amphibole. In other cases very fine, skeletal-looking olivines are arranged in parallel bars, which occur as randomly oriented sets.

Late, relatively undeformed layered, ultrabasic-gabbroic rocks also occur. The ultrabasic portions have layers of magnetite and dunite demonstrating a relict cumulate texture. This is in part recrystallised to granular olivine set with euhedral magnetites. The margins of the body have suffered hydration and now consist of a chlorite groundmass in which are scattered 2-5 cm diameter garnets and many small magnetites.

Several basic dykes cut the Ivisârtoq amphibolites and meta-sediments, in each case consisting of a homogeneous, grey-black amphibolite. Usually the dykes have clearly discordant boundaries and may be traced for several metres. These dykes are not comparable with the Ameralik dykes since they are both far less abundant and relatively undeformed. 
As the Ivisârtoq complex rocks are generally less deformed and metamorphosed than the Akilia suite, the two supracrustal sequences are structurally and lithologically distinct.

\section{Younger Anorthosites}

A $1 \mathrm{~km}$ thick unit of anorthositic rocks occurs adjacent to the Ivisârtoq amphibolites in the south of the area. The contact of the anorthosites with the amphibolites is tectonic and no original relationships were observed. Most frequently the boundary consists of an irregular interlayering of boudinaged amphibolite, anorthosite and meta-sediments. The true thickness is impossible to estimate because of considerable dilation due to intrusive granitic material. Large rafts and many small xenoliths of anorthosite in the gneisses to the south of the main unit, suggest that the unit was once much thicker.

Generally the most mafic portions of the body occur in association with the most anorthositic fractions, near the amphibolite contact. A more uniform leucogabbro occurs away from this zone in which the grain sizes of the euhedral plagioclase crystals vary from $0.2-15$ $\mathrm{cm}$ in diameter. These occur with interstitial hornblende as a preserved igneous cumulate texture. Usually plagioclase crystals are of similar size in any one horizon, but locally larger crystals $(c .10 \mathrm{~cm})$ occur in a matrix consisting of smaller $(c .4 \mathrm{~cm})$ crystals and interstitial hornblende.

Way-up directions can be estimated from locally preserved gravity stratified layering of hornblende and plagioclase, but are inconsistant because of local folding. The deformation of the anorthosite has been extremely inhomogeneous, resulting in sub-rounded or tabular masses of essentially undeformed leucogabbro set in a highly foliated, schistose matrix.

\section{Nûk Gneisses}

An important relationship between the Amîtsoq and younger Nûk gneisses may be observed on Kangilingua. Here the Amitsoq gneisses have been split up parallel to their planar fabric by sheets of homogeneous, grey Nûk gneiss and pegmatite. This sheeting is found on all scales up to $400 \mathrm{~m}$ thick. Eastwards the intrusive material becomes mainly pegmatitic and less dominant. Westwards, towards Naujat kingingnerat (fig. 15), banded Amîtsoq gneisses occur as isolated rafts which are lithologically and structurally distinct from the essentially homogeneous, relatively undeformed intrusive Nûk gneiss. The Amîtsoq rafts become completely broken up so that Akilia, Amîtsoq gneiss and Ameralik dyke lithologies occur as discrete agmatitic blocks within Nûk gneisses. Such relationships also exist in the Amitsoq complex rocks in the west of the area.

Similar sheeting relationships are found at many Ivisârtoq amphibolite complex - Nûk gneiss interfaces. Large elongate rafts of amphibolite bounded by foliation surfaces occur in the gneisses directly beneath the contact, away from which the rafts become progressively broken up into trains of boudins and enclaves.

Later phases of the Nûk gneisses cut the earlier, agmatitic and pegmatite banded gneisses. These later phases occasionally contain clots of quartz and minor feldspars, or felsic segregations with biotite cores, which form augen upon deformation. 
Table 1. Simplified stratigraphic sequence of events in the Ivisârtoq area, West Greenland

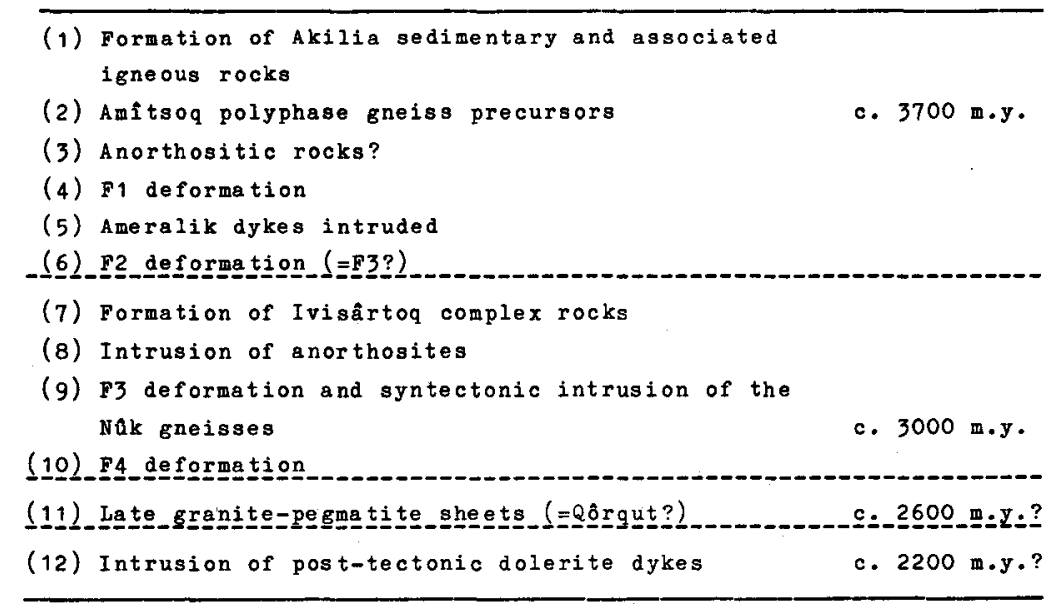

\section{Late Granite-pegmatite Sheets}

Granite and pegmatite sheets occur within the Ivisârtoq amphibolite complex which was recognised on structural grounds to be younger than the Nûk gneisses. The granites are at most only weakly foliated and are never lineated, in contrast to the Nûk gneisses. The sheets are composed of a very leucocratic, homogeneous, often garnetiferous granitic rock which grades into pegmatite. These rocks are possibly the equivalents of the Qôrqut granite (McGregor, 1973).

\section{Structure}

Almost the entire Archaean stratigraphy of West Greenland appears to be represented in the Ivisârtoq area. The details of the complex structural history are beyond the scope of this report. A preliminary and simplified sequence of events is given in Table 1 .

Several generations of fabric are incorporated in the Amitsoq gneiss complex. These are considered as pre- and post-Ameralik dyke (F1 and $\mathrm{F} 2$ respectively) deformational events. Because of little direct contact between the Amitsoq gneisses and the Ivisârtoq amphibolites it is difficult to determine whether or not the F2 deformation affects the younger rocks. The first major folds within the Ivisârtoq amphibolite complex (F3) are responsible for the closure near Naujat kingingnerat. This structure is then refolded by a steeply inclined antiform (F4) which plunges south-west and produces the present outcrop patterns.

\section{References}

Baadsgaard, H. 1976: Further U-Pb dates on zircons from the early Precambrian rocks of the Godthaabsfjord area, West Greenland. Earth Planet. Sci. Lett. 33, 261-267. 
Black, L. P., Gale, N. H., Moorbath, S., Pankhurst, R. J. \& McGregor, V. R. 1971: Isotopic dating of very early Precambrian amphibolite facies gneisses from the Godthaab district, West Greenland. Earth Planet. Sci. Lett. 12, 245-259.

Bridgwater, D., Keto, L., McGregor, V. R. \& Myers, J. S. 1976: Archaean gneiss complex of Greenland. In Escher, A. \& Watt, W. S. (edit.) Geology of Greenland, 18-75. Copenhagen: Geol. Surv. Greenland.

Dawes, P. R. 1970: Bedrock geology of the nunataks and semi-nunataks of the Frederikshåbs Isblink area of southern West Greenland. Rapp. Grønlands geol. Unders. 29, 60 pp.

Friend, C. R. L. 1975: The geology and geochemistry of the Pre-ketilidian basement complex in the Ravns Storø area, Fiskenaesset Region, southern West Greenland. Unpub. thesis Univ. London. McGregor, V. R. 1973: The early Precambrian gneisses of the Godthåb district, West Greenland. Phil. Trans. R. Soc. Lond. A 273, 343-358.

McGregor, V. R. \& Bridgwater, D. 1973: Field mapping of the Precambrian basement in the Godthåbsfjord district, southern West Greenland. Rapp. Grønlands geol. Unders. 55, 29-32.

McGregor, V. R. \& Mason, B. in press: Petrogenesis and geochemistry of metabasaltic and metasedimentary enclaves in the $3700 \mathrm{~m}$.y. Amitsoq gneisses of the Godthåb region, West Greenland. Amer. Miner.

Moorbath, S., O'Nions, R. K., Pankhurst, R. J., Gale, N. H. \& McGregor, V. R. 1972: Further rubidium-strontium age determinations of the very early Precambrian rocks of the Godthaab district, West Greenland. Nature Phys. Sci. 240, 78-82.

Moorbath, S. \& Pankhurst, R. J. 1976: Further rubidium-strontium age and isotope evidence for the nature of the late Archaean plutonic event in West Greenland. Nature 262, 124-126.

Pankhurst, R. J., Moorbath, S. \& McGregor, V. R. 1973: Late event in the geological evolution of the Godthaab district, West Greenland. Nature Phys. Sci. 243, 24-26.

Pulvertaft, T. C. R. 1968: The Precambrian stratigraphy of western Greenland. Rep. 23rd int. geol. Congr. Prague 4, 89-107.

C.R.L.F.,

Department of Science,

Oxford Polytechnic,

Headington,

Oxford OX3 OBP,

U.K.
R.P.H., Department of Chemistry and Geology, Portsmouth Polytechnic, Burnaby Road, Portsmouth POI $3 Q L$, U.K.

\title{
Field work on Precambrian rocks in the Buksefjorden region, southern West Greenland
}

\author{
Brian Chadwick, Kenneth Coe, Paul M. Compton and Allen Nutman
}

Four teams took part in field work in the 1976 season, the penultimate in the project started in 1972 to map the 1:100000 scale Buksefjorden sheet. Chadwick completed mapping Angissorssuaq and surrounding islands; Coe worked between Taserssuatssiat and Alángor- 